\title{
New locality records for two hypogeous basidiomycete species in Turkey
}

\section{Ant J Bot 1.}

Received : 18.02.2019 Accepted : 24.03.2019 Online $\cdot 02.04 .2019$

\author{
Semiha YAKAR ${ }^{1} \odot$, Yasin UZUN ${ }^{1 * \odot}$, Fahri Tunahan ÇEVIK ${ }^{2} \odot$ \\ ${ }_{1}^{1}$ Karamanoğlu Mehmetbey University, Kamil Özdağ ScienceFaculty, Department of Biology, Karaman, Turkey \\ ${ }^{2}$ Yunuskent Mehmet Akif Ersoy Anatolian High School, Karaman, Turkey \\ *yasinuzun_61@hotmail.com
}

\section{İki toprakaltı bazidiyomiset türü için Türkiye'de yeni lokalite kayıtları}

Abstract: New specimens of two previously recorded hypogeous basidiomycete species, Alpova diplophloeus (Zeller \& C.W. Dodge) Trappe \& A.H. Sm. and Schenella pityophila (Malençon \& Riousset) Estrada \& Lado, were collected from Eastern Black Sea and Central Anatolian regions, and reported for the second time from Turkey. New distribution localities and brief descriptions of the species were provided together with the photographs related to their macro and micromorphologies.

Key words: Alpova, biodiversity, hypogeous fungi, Schenella, Turkey

Özet: Daha önceden kaydedilmiş olan iki toprakaltı bazidiyomiset türüne, Alpova diplophloeus (Zeller \& C.W. Dodge) Trappe \& A.H. Sm. ve Schenella pityophila (Malençon \& Riousset) Estrada \& Lado, ait örnekler Doğu Karadeniz ve İç Anadolu bölgeleri'nden toplanarak Türkiye'den ikinci kez rapor edilmiştir. Türlerin yeni yayılış lokaliteleri ve kısa betimlemeleri, makro ve mikromorfolojilerine ait fotoğrafları ile birlikte verilmiştir.

Anahtar Kelimeler: Alpova, biyoçeşitlilik, toprakaltı mantarlar, Schenella, Türkiye

\section{Introduction}

Alpova CW.Dodge and Schenella Malençon \& Riousset are two hypogeous basidiomycete genera within the families Paxillaceae and Geastraceae. Alpova was first discovered by L.E. Vehmeyer and C.H. Kauffman (Zeller, 1939) in 1922 and is characterized by globose to irregular basidiocarps; well developed and variably thickened peridium; solid gleba with gell-filled chambers seperated by pallid veins; hyaline to yellow or light grayish brown, ellipsoid, obovoid, reniform or irregular basidiospores (Dodge, 1931; Trappe, 1975; Beaton et al., 1985). Schenella was first described by Thomas Huston Macbride (1911) and is characterized by hypogeous to erumpent, indehiscent, globose to subglobose basidiomata, two to three layered peridium, powdery or peridiolated mature gleba, distinct columella, elastic, nonseptate and smooth capillitial threads, tubular, filiform, thin walled and hyaline basidia, and ellipsoidal to globose basidiospores (Domínguez de Toledo and Castellano, 1996).

During field studies in Konya, Rize and Trabzon provinces, some hypogeous basidiomycete samples were collected and identified as Alpova diplophloeus (Zeller \& C.W.Dodge) Trappe \& A.H. Sm. and Schenella pityophila (Malençon \& Riousset) Estrada \& Lado. Tracing the current literature it was found that both taxa have only one mention in Turkey.

The study aims to make a contribution to the mycobiota of Turkey by presenting new distributions for two hypogeous basidiomycete taxa.

\section{Materials and Method}

Shenella samples were collected from Ereğli district of Konya (Central Anatolian Region), and Alpova samples were collected from Rize and Trabzon (Eastern Black Sea Region) provinces. All the samples were photographed at their natural habitats and the ecological and descriptive characteristics were recorded during field studies. Then the samples were transferred to the fungarium and dried in an air conditioned room before preparing as fungarium materials. Macroscopic and microscopic measurements were performed on dried samples in the fungarium. A Nikon Eclipse Ci-S trinocular light microscope were used for micromorphological investigations. Photographs related to micromorphology were taken by a DS-Fi2 digital camera aided by a Nikon DS-L3 displaying apparatus through the same trinocular microscope. The specimens were identified by comparing the obtained data with Zeller and Dodge (1918), Trappe (1975), Gross (1980), Domínguez de Toledo and Castellano (1996), Venturella et al. (2004), Trappe et al. (2007), Signore et al. (2008), Trappe et al. (2009), D'Auria et al. (2013) and Hayward et al. (2014).

The specimens are kept at Biology Department, Kamil Özdağ Science Faculty, Karamanoğlu Mehmetbey University.

\section{Results}

Basidiomycota R.T. Moore

Boletales E.-J. Gilbert

Paxillaceae Lotsy

Alpova diplophloeus (Zeller \& C.W.Dodge) Trappe \& A.H. Sm., Beih. Nova Hedwigia 51: 286 (1975)

[Syn: Alpova diplophloeus (Zeller \& C.W.Dodge) Trappe \& A.H.Sm. f. diplophloeus, Alpova diplophloeus f. europaeus Trappe, Rhizopogon diplophloeus Zeller \& C.W.Dodge]

Basidiomata 20-40(-50) mm, globose, ovoid, irregular to reniform. Peridium up to $1 \mathrm{~mm}$ thick, yellowish to yellowish-brown, surface smooth, somewhat pruinose in young samples, yellowish-brown to brownish. Gleba sticky-gelatinous with gelfilled chambers of $0.5-2.5 \mathrm{~mm}$ broad and separated by yellow veins, pale yellow to reddish brown and finally dark brown (Fig. 1). Odor fruity. Basidia $10-15 \times 4-5 \mu \mathrm{m}$, clavate, hyaline. 
Basidiospores 4-5.6×2.1-2.7 $\mu \mathrm{m}$, ellipsoid, rarely allantoid to reniform, smooth (Fig. 2).

Ecology: Alpova diplophloeus was reported to grow as a mychorrizal associate among roots of Alnus spp. (Trappe et al., 1975, 2007). Trappe et al. (2009) claims $A$. diphophloeus as a strictly Alnus asscociate.
Specimen examined: Turkey - Rize, Ardeșen, Yukarıdurak Village, mixed forest, in soil around Alnus sp. roots, $41^{\circ} 05^{\prime} \mathrm{N}-41^{\circ} 06^{\prime} \mathrm{E}, 925 \mathrm{~m}, 12.08 .2017$, Yuzun 5782; Trabzon, Tonya, Erikbeli Village, mixed forest, in soil around Alnus sp. roots, $40^{\circ} 45^{\prime} \mathrm{N}-39^{\circ} 14^{\prime} \mathrm{E}, 1680 \mathrm{~m}$, 22.09.2015, Yuzun 4610; Yomra, Özdil Village, Alnus sp. forest, $40^{\circ} 50^{\prime} \mathrm{N}-39^{\circ} 48^{\prime} \mathrm{E}, 1210 \mathrm{~m}, 25.08 .2018$, Yuzun 6684;
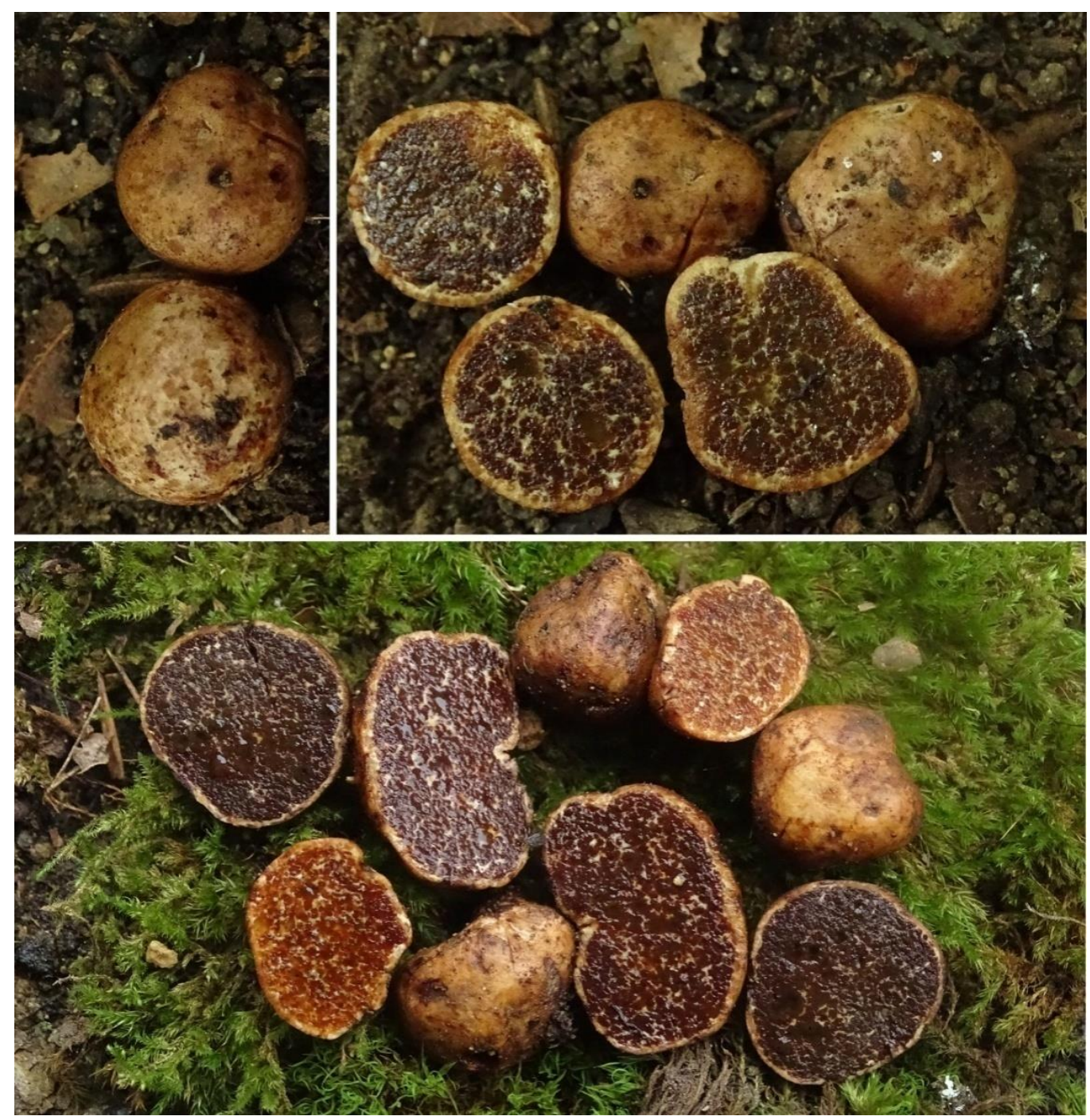

Figure 1. Basidiocarps of Alpova diplophloeus

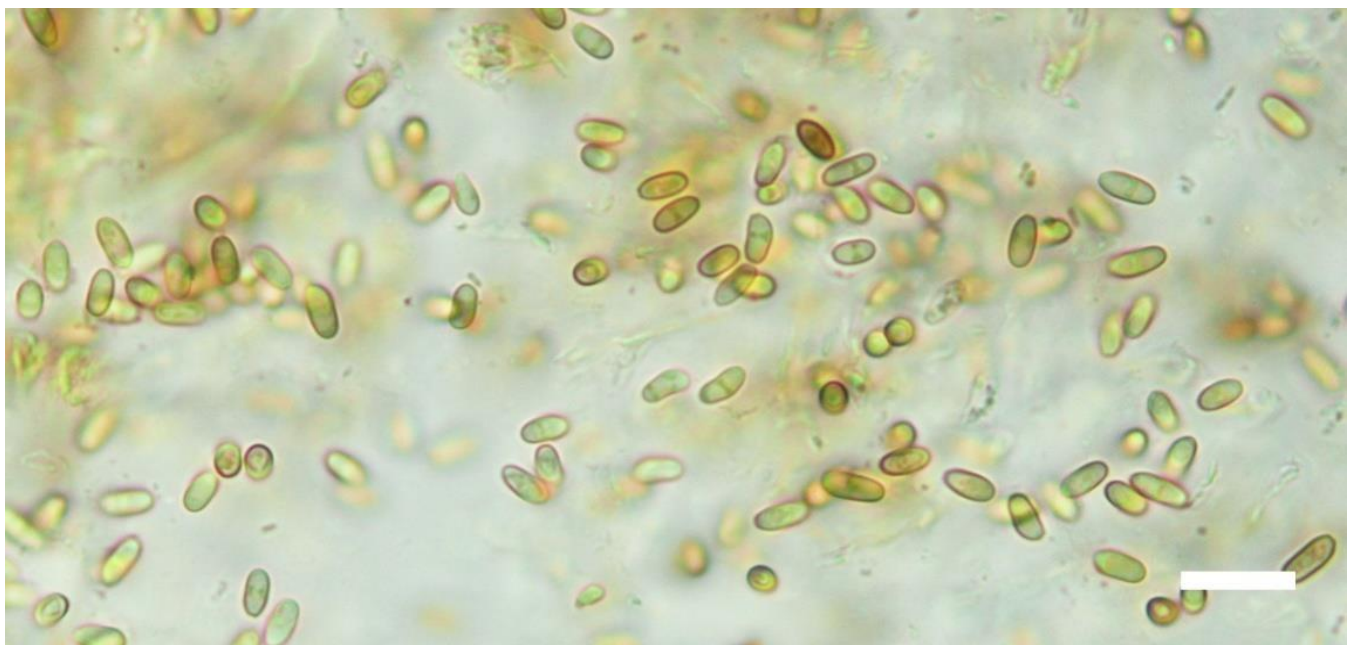

Figure 2. Basidiospores of Alpova diplophloeus (Melzer's solution) (bar $10 \mu \mathrm{m})$ 

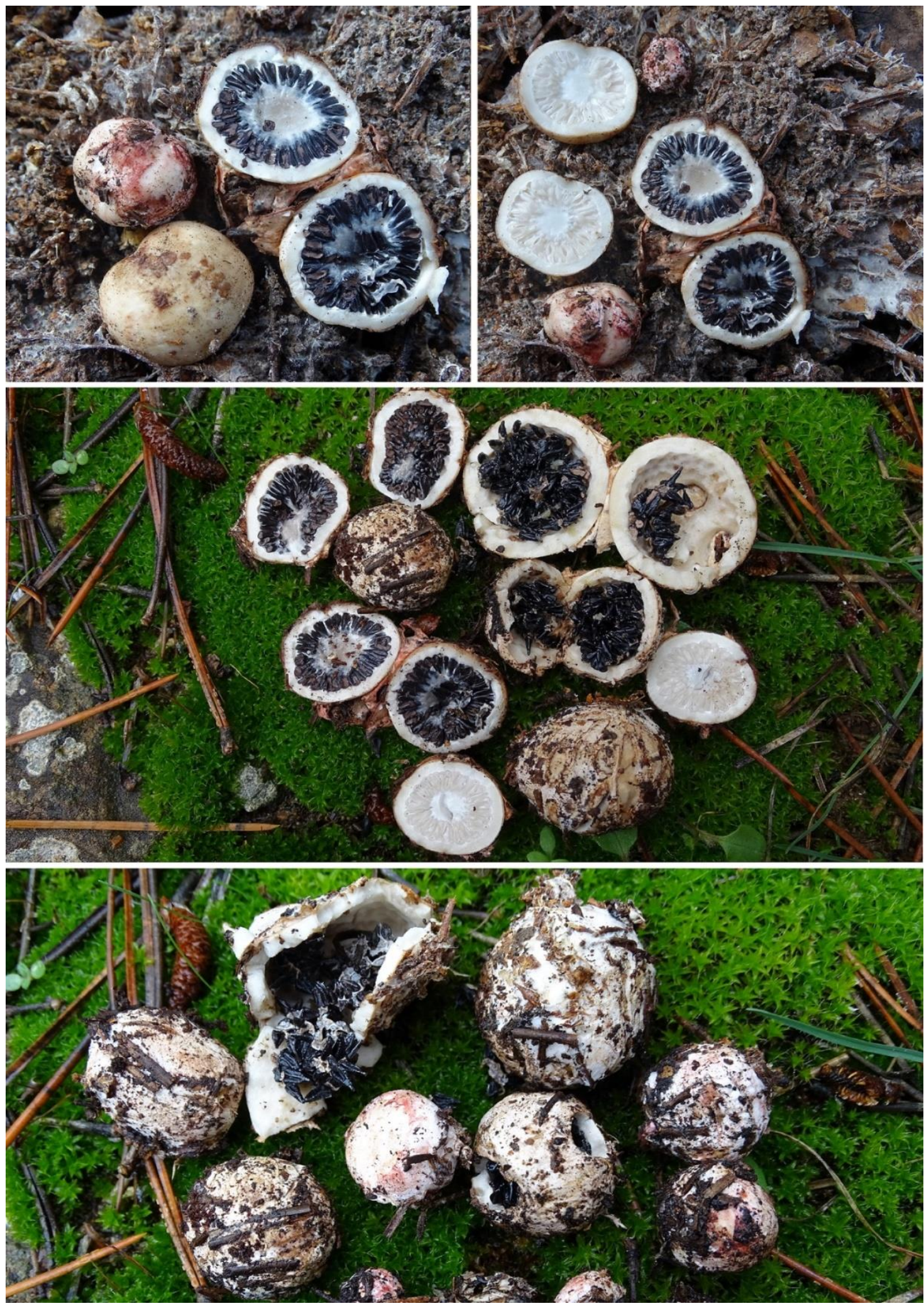

Figure 3. Basidiocarps of Schenella pityophila

Central district, Esenyurt Village, mixed forest, in soil under Alnus sp., $40^{\circ} 53^{\prime} \mathrm{N}-39^{\circ} 45^{\prime} \mathrm{E}, 745 \mathrm{~m}, 30.08 .2018$, Yuzun $6740 ; 40^{\circ} 54^{\prime} \mathrm{N}-39^{\circ} 45^{\prime} \mathrm{E}, 660 \mathrm{~m}, 02.09 .2018$, Yuzun 6754.

Alpova diplophloeus is the second member of the genus Alpova in Turkey. The first member of the genus, Alpova corsicus P.-A.Moreau \& F.Rich., was reported by Türkoğlu et al. (2015). Though not reported in a paper,
Alpova diplophloeus was also declared as new record fromTurkey by Türkoğlu A, Castellano MA, Trappe JM, Yaratanakul Güngör $M$ in 2014 during Second Symposium on Hypogeous Fungi in Mediterranean Basin (HYPOGES2) \& Fifth Congress Tuber aestivum/uncinatum European Scienctific Group (TAUESG5) in Rabat-Morocco. That's why our collection was regarded as the second in Turkey. 
Geastrales K. Hosaka \& Castellano

Geastraceae Corda

Schenella pityophila (Malençon \& Riousset) Estrada \& Lado, Mycologia 97(1): 147 (2005)

\section{[Syn:Pyrenogaster pityophilus Malençon \& Riousset]}

Macroscopic and microscopic features: Basidiomata hypogeous, $10-25 \mathrm{~mm}$ in diameter, spherical to ellipsoidal (Fig. 3). Peridium three layered. Exoperidium felty to cottony, easily separable, covered by numerous mycelial residues (Fig. 4a,b), that adhere part of the substrate, whitish to light ochraceous, turns red to pink when handled or exposed to the air. Mesoperidium white, fleshy, hard and compact. Endoperidium white, membranous and soft. Gleba composed of a round basal pseudocolumella, in which 150-200 conical or pyramidal and $3-1.5 \mathrm{~mm}$ peridioles are placed radially, white and firm when young, black and dehiscent when mature (Fig. 3). Basidia 35-40 × 2-3 $\mu \mathrm{m}$, filiform, hyaline, enlarged towards the apex up to $4 \mu \mathrm{m}$. Sterigmata $2-8$, fingershaped, 3-5 $\times$ 0.5-0.6 $\mu \mathrm{m}$. Basidiospores ellipsoidal, radially symmetrical, $7.5-12 \times 5-7.5 \mu \mathrm{m}$, smooth hyaline and thin-walled when young, 7-8 $\times 5-7 \mu \mathrm{m}$, finely verrucose and apiculated when mature (Fig. $4 d, e$ ).

Ecology: Schenella pityophila was reported to grow under Douglas-fir and oak trees (Trappe et al., 2007), $P$. halepensis (Rana et al., 2015), P. ponderosa, P. jeffreyi and Arbutus menziesii (Reha and Southworth, 2015)

Schenella pityophila was reported previously from Turkey only once from the locality in Köyceğiz district of Muğla province (Doğan, 2018).

Specimen examined: Turkey - Konya, Ereğli, Sarıca Village, pine forest, roadside, in soil, $37^{\circ} 27^{\prime} \mathrm{N}-34^{\circ} 07^{\prime}$ E, $1100 \mathrm{~m}, 30.12 .2017$, FTÇ 270.

\section{Discussions}

New collections of two hypogeous basidiomycete species, Alpova diplophloeus and Schenella pityophila, were reported. Both taxa have previously been presented from Turkey only once.

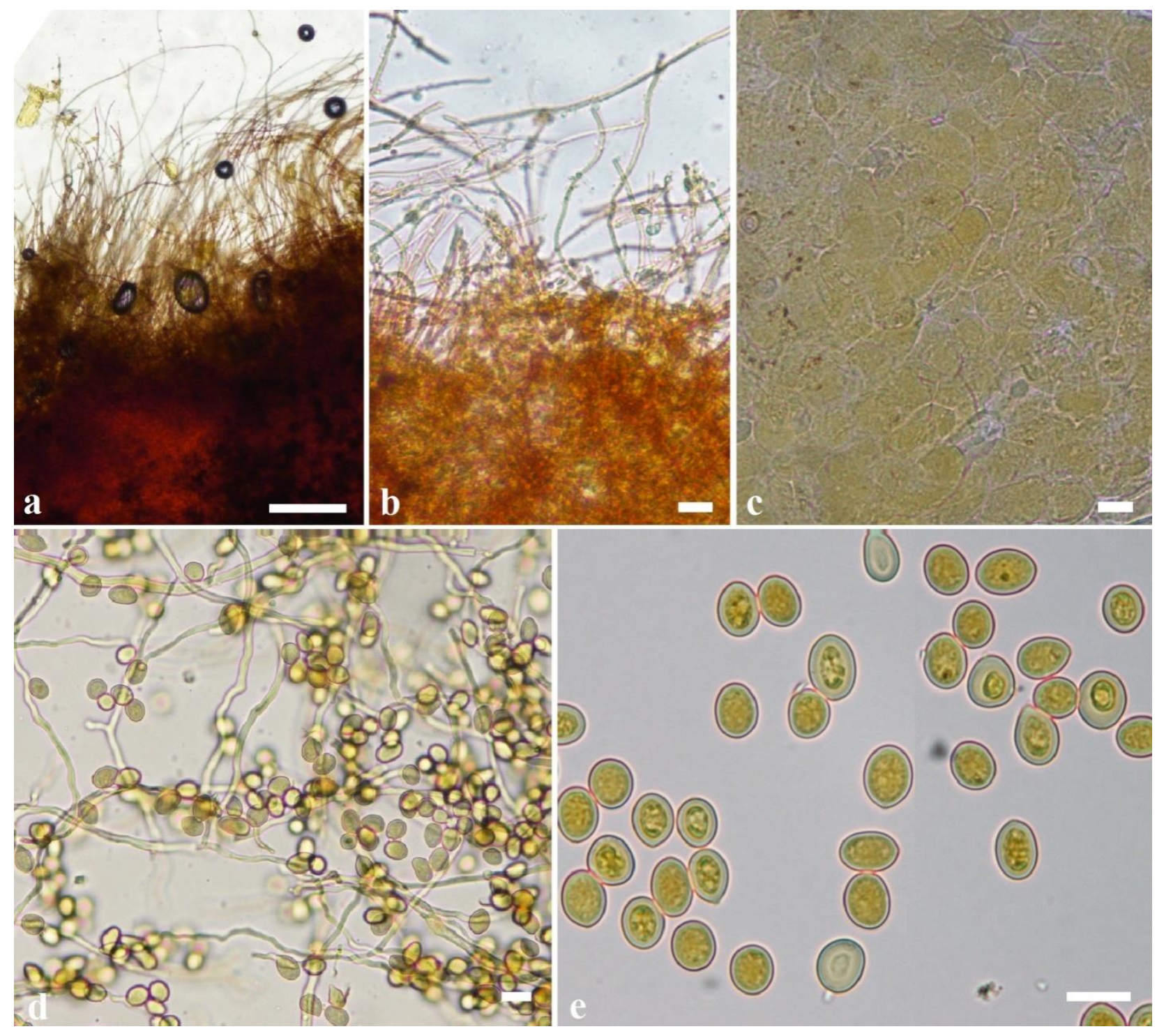

Figure 4. Mycelial layer on exoperidium (a,b), endoperidium (c) and basidiospores (d,e) of Schenella pityophila (a,b: Congo red, c,d,e: Melzer's solution) (bars a: $100 \mu \mathrm{m}, \mathrm{b}-\mathrm{e}: 10 \mu \mathrm{m})$ 
Alpova diplophloeus is a member of the order Boletales and sixteen hypogeous members of this order belonging to four families and five genera (Octaviania Vittad., Alpova C.W.Dodge, Melanogaster Corda, Rhizopogon Fr., Sclerogaster R.Hesse) have so far been reported from Turkey (Demirel, 1996; Kaşık et al., 2002; Sesli and Castellano, 2009; Uzun et al., 2014; Sesli and Moreau, 2015; Türkoğlu et al., 2015; Elliot et al., 2016; Allı et al., 2017; Öztürk et al., 2017; Türkekul, 2017; Kaygusuz et al., 2018; Uzun et al., 2019)

Schenella pityophila is a member of the the family Geastraceae and 20 members of this family belonging to four genera (Geastrum Pers., Myriostoma Desv., Schenella and Sphaerobolus Tode) have been reported from Turkey (Sesli and Denchev, 2014; Doğan, 2018).

General macro- and micromorphological characteristics of the studied samples of A. diphopholeus and S. pityophila are in aggreement with thoose given in literature.

\section{Acknowledgments}

Authors would like to thank Ömer UZUN, Doğancan KUDUBAN, Yücel UZUN and Hasan UZUN for their kind help during the collection of Alpova samples.

\section{References}

All1 H, Candar SS, Akata I (2017). Macrofungal Diversity of Yalova Province. The Journal of Fungus 8(2): 76-84.

Beaton G, Pegler DN, Young TWK (1985). Gasteroid Basidiomycota of Victoria State, Australia: 5-7. Kew Bulletin 40(3): 573598.

D’Auria M, Racioppi R, Rana GL(2013). Volatile organic compounds of Schenella pityophilus. Natural Product Research 27(1): 41-44.

Demirel K (1996). Two new records of Gasteromycetes for Turkey. Yüzüncü Y1l Üniversitesi Journal of Faculty of Education 1: 136-139.

Dodge CW (1931). Alpova, a new genus of Rhizopogonaceae, with further notes on Leucogaster and Arcangeliella. Annals of the Missouri Botanical Garden 18(3): 457-464.

Doğan HH (2018). A new Genus, Schenella, Addition to Turkish Mycota from Geastraceae. The Journal of Fungus 9(2): 92-94.

Domínguez de Toledo LS, Castellano MA (1996). A revision of the genera Radiigera and Pyrenogaster. Mycologia 88(5): 863884.

Elliot TF, Türkoğlu A, Trappe JM, Yaratanakul Güngör M (2016). Turkish truffles 2: eight new records from Anatolia. Mycotaxon 131(2): 439-453.

Gross G (1980). Notes on some recent collections of Alpova in the Bavarian Alps. Zeitschrift für Mykologie 46(1): 21-26 (in German).

Hayward J, Tourtellot SG, Horton TR (2014). A revision of the Alpova diplophloeus complex in North America. Mycologia 106(4): 846-855.

Kaşık G, Türkoğlu A, Öztürk C, Doğan HH (2002). Macrofungi of Develi (Kayseri). Selçuk Üniversitesi Fen Edebiyat Fakültesi Fen Dergisi 20: 49-54.

Kaygusuz O, Çolak ÖF, Matočec N, Kušan I (2018). New Data on Turkish Hypogeous Fungi. Natura Croatica 27(2): $257-269$.

Macbride TH (1911). A new genus of Myxomycetes. Mycologia 3: 39-41.

Öztürk C, Pamukçu D, Aktaş S (2017). Nallıhan (Ankara) İlçesi Makrofungusları. Mantar Dergisi 8(1): 60-67.

Rana GL, Mang SM, Camele I (2015) Biodiversity of Hypogeous Fungi in Basilicata. In: Vastola A. (eds) The Sustainability of Agro-Food and Natural Resource Systems in the Mediterranean Basin. Cham.: Springer,pp 305-318.

Reha C, Southworth D (2015). Stable isotope evidence for the saprotrophic statusof the truffle Schenella pityophilus. North American Fungi 10(1): 1-7.

Sesli E, Castellano MA (2009). Rhizopogon marchii (Basidiomycota, Rhizopogonaceae), a new record from Turkey. The Herb Journal of Systematic Botany 16(1): 155-158.

Sesli E., Denchev C.M. (2014). Checklists of the myxomycetes, larger ascomycetes, and larger basidiomycetes in Turkey. 6th edn. Mycotaxon Checklists Online (http://www.mycotaxon.com/resources/checklists/sesli-v106-checklist.pdf): 1-136.

Sesli E, Moreau PA (2015). Taxonomic studies on some new fungal records from Trabzon, Turkey. Turkish Journal of Botany 39(5): 857-866.

Signore SF, Rana GL, Lolli G, Laurita A (2008). Schenella pityophilus, un raro gasteromicete rinvenuto nel Salento. Micol Veget Medit 23:135-145.

Trappe JM (1975). A Revision of the Genus Alpova with Notes on Rhizopogon and the MeIanogastraceae. Beihefte zur Nova Hedwigia 51: 279-310.

Trappe M, Evans F, Trappe J (2007). Field guide to North American Truffles. New York: Ten Speed Press.

Trappe JM, Molina R, Luoma DL, Cázares E, Pilz D, Smith JE, Castellano MA, Miller SL, Trappe MJ (2009). Diversity, ecology, and conservation of truffle fungi in forests of the Pacific Northwest. General Technical Report, Portland: United States Department of Agriculture Forest Service.

Türkekul İ (2017). New Calbovista, Mycena, Rhizopogon, Stictis, and Symphyosirinia records from Turkey. Mycotaxon 132(2): 503-512. 
Türkoğlu A, Castellano MA, Trappe JM, Yaratanakul Güngör M (2015). Turkish truffles I: 18 new records for Turkey. Turkish Journal of Botany 39(2): 359-376.

Uzun Y, Acar İ, Akata A (2014). Notes on Turkish Melanogaster. The Herb Journal of Sytematic Botany 21(2): 113-118.

Uzun Y, Kaya A, Yakar S (2019). A new record and new localities for the genus Sclerogaster R.Hesse in Turkey. Süleyman Demirel University Journal of Natural and Applied Sciences, Volume 23, Special Issue, 9-12.

Venturella G, Saitta A, Morara M, Zambonelli A (2004). Pyrenogaster pityophilus (Geastraceae). A new record from Sicily (SItaly). Flora Mediterranea 14: 263-266.

Zeller SM (1939). Developmental Morphology of Alpova. Oregon: Oregon State College.

Zeller SM, Dodge CW (1918). Rhizopogon in North America. Annals of the Missouri Botanical Garden 5(1): 1-36.

Cite this article: Yakar S, Uzun Y, Çevik FT (2019). New locality records for two hypogeous basidiomycete species in Turkey. Anatolian Journal of Botany 3(1): 28-33. 